\title{
Practs in First Official Speeches of Presidents Muhammadu Buhari and Nana Akufo-Addo on Coronavirus Pandemic
}

\author{
Bibian Ugoala1, Peace Chinwendu Israel ${ }^{2}$ \\ ${ }^{1}$ Faculty of Arts, Department of Languages, National Open University of Nigeria, Lagos, Nigeria \\ ${ }^{2}$ Faculty of Foreign Languages Education and Communication, University of Education, Winneba, Ghana \\ Email: bugoala@noun.edu.ng, peacenwendu@gmail.com
}

How to cite this paper: Ugoala, B., \& Israel, P. C. (2020). Practs in First Official Speeches of Presidents Muhammadu Buhari and Nana Akufo-Addo on Coronavirus Pandemic. Open Journal of Modern Linguistics, 10, 740-764.

https://doi.org/10.4236/ojml.2020.106045

Received: October 29, 2020

Accepted: November 22, 2020

Published: November 25, 2020

Copyright $\odot 2020$ by author(s) and Scientific Research Publishing Inc. This work is licensed under the Creative Commons Attribution International License (CC BY 4.0).

http://creativecommons.org/licenses/by/4.0/

\begin{abstract}
This paper examined first official speeches of presidents of Nigeria and Ghana on coronavirus pandemic. The study adopted content analytical method which involves qualitative and quantitative method of data analysis and presentation. Applying concepts from Pragmatics act, the study revealed different practs through which both presidents made their intentions known towards combating the virus. It was discovered that President Muhammadu Buhari deployed 95 practs in order to achieve five pragmatic functions namely: to reveal achievements and further action (53.69\%), to instruct and direct (28.41\%), to commend (4.21\%), to pacify/encourage (10.53\%), and to persuade (3.16\%). President Nana Akufo-Addo deployed 39 practs to achieve six pragmatic functions: to reveal achievements and further action $(56.41 \%)$, to instruct and direct (25.64\%), to pacify (7.69\%), to commendation (5.13\%), persuasion (2.56\%), and to warn (2.56\%). It was discovered that shared situational knowledge, reference and inference enable the citizens of both countries to understand what both presidents wish to communicate especially where both presidents used words and phrases to refer to coronavirus. The paper concluded that through the analysis of different practs in speeches, thematic focus of a speech can be discerned.
\end{abstract}

\section{Keywords}

Practs, Coronavirus, Political Speech, President Muhammadu Buhari, President Nana Akufo-Addo

\section{Introduction}

The coronavirus COVID-19 pandemic is the defining global health crisis the 
world has ever known and the greatest challenge the world has faced since World War Two. It stretched around the world and left everyone grappling with an invisible, deadly enemy. In a bid to find a suitable solution to this, many measures were taken and are still being taking by different people, organisations and countries. Some of the measures include videos, text messages, radio/television jingles and speeches. The uniting theme in all of these different outlets of messages is the need for people to be aware of the deadly nature of the virus and take precaution. Presidents and leaders of countries lent their voices through official speeches as a way to curb the spread of the deadly disease. Presidential speech is very important in the affairs and smooth running of a nation. Often times, the speech is delivered with specific intentions and goals. The Presidential speeches of Nigerian President, Muhammadu Buhari (PMB) and Ghanaian President, Nana Akufo-Addo (PNA-A) have been selected for this study.

Over the years, political speeches have been very powerful and influential in nature. Political communication includes speeches that are delivered by politicians, election campaigns, parliamentary debates, political interviews, campaigns, manifestoes, inaugural speeches, and Independence Day speeches. Political discourse has become a popular concept of discourse analysis. Within all types of political system, political leaders, by virtue of their position play a critical role in national development and international politics and rely on words to influence, mobilize, persuade and convince their citizens in order to achieve effective governance. Consequently, presidential speeches about coronavirus pandemic have become an effective tool for the management of the virus all over the world. Ayeomoni and Akinkuolere (2012) explain that language is a powerful tool in the hands of political leaders for manipulation purposes. Iyengar (2005) states that "specific words and phrases ... have the ability to elicit core value systems". When people speak, they perform some acts; the acts enable the hearer of speech to take some form of action.

A cursory search for scholarly works which focus on both speeches of PMB of Nigeria and PNA-A of Ghana, shows that no work has focused analysis on both Presidents. The works found have focused on them separately. Some of the works carried out on PMB for example include the following: Koussouhon and Dosoumou (2015) subjected PMB's inaugural speech to critical discourse analysis (CDA). Ademilokun (2015) examined aspects of attitudinal meaning in PMB's inauguration speech, using Appraisal Theory of Martin and White (2005). Medubi and Amuda (2016) carried out a socio-pragmatic analysis of PMB's inaugural address with a view to elucidating "the meanings encoded in the inaugural and the functions they perform in an actual context of use". Okafor and Issife (2017) examined choice of mood and modality in PMB's inaugural speech with a view to determining their functional significance. Ugoala (2017) investigated the semantic and textual cohesive devices in PMB's directive to Service Chiefs with respect to quashing Boko Haram menace in Nigeria. The study adopted content analytical method and Language Expectancy Theory by Burgoon, Jones and Stewart (1975), the study found that that there exist identifiable 
semantic relationships among words in PMB's directive to the Service Chief, the semantic relations helped PMB to convey his thoughts to Service Chiefs. Isa \& Abaya (2019) carried out a critical discourse analysis of PMB's and President Goodluck Jonathan's use of rhetorical devices in 2011 presidential election in Nigeria. The study found that both speakers used rhetorical devices to persuade and appeal to the audience to attain political power. In relation to PNA-A, Kyei, Donkor and Appiah (2020) investigated the move structure and linguistic characteristics of PNA-A's 2017 inaugural speech. Dadjo (2018) through speech act theory, investigated two selected speeches by PNA-A about Africa's Dependency on the West. Israel \& Botchwey (2017) examined inaugural addresses in the $4^{\text {th }}$ republic of Ghana with a concentration on PNA-A's. Adukpo, (2017) analysed the registers and lexical cohesion in his political manifesto. Kantorgorje (2020) explored epistemic modality of selected (including PNA-A's) inaugural speeches.

\section{The Aim of the Study}

This study examines types and classes of practs in the speeches of Nigerian President, PMB, and that of Ghanaian President, PNA-A. It is a comparative study whose aims are to reveal the various practs through which both presidents connected with their audience in the bid to curb coronavirus pandemic and to examine their degree of urgency as well.

\section{Objectives of the Study}

The objectives of the study are to:

- examine the frequencies of pragmatic acts performed in the speeches of PMB, and PNA-A,

- highlight words/phrases that act as contextual inferences of coronavirus in both speeches,

- identify similar and dissimilar practs in both speeches.

\section{Pragmatic Acts Theory (PAT)}

The theory underpinning this study is Pragmatic acts theory by Mey (2001). Also, pragmatic concepts of Shared Situational Knowledge (SSK), and inference were applied in the analysis. The Pragmatic acts theory is a response to some inadequacies of Austin's Speech Act Theory (SAT). Some of the identified inadequacies include the fact that the SAT excludes context in the analysis of utterances. Pragmatic acts theory according to Mey is a theory that sees context as action against Austin's claim of context as reference. Austin claims that people do things with words when they speak. Mey (2001) argues that "There are no speech acts but only situated speech acts or instantiated pragmatic acts". Pragmatic acts involve "adapting oneself to context as well as adapting context to oneself"; in other words, context plays a great role in determining the meaning of utterances. Pragmatic acts always comprise an "agent" and an "act". An individual's agent is the individual's history that helps in the interpretation of a cur- 
rent discourse, this history according to Fairclough (1998), is often referred to as "background knowledge". Which is shared, apriori and naturally facilitates the meaning making process. The second component of pragmatic acts-the act-refers to the relationship between linguistic expressions, situation of use, and context of use; this brings out clearly the meaning of particular instance of communication. Pragmatic analysis focuses also on how language can be used to create the conditions necessary to perform a pragmatic act. Mey (2001) submits that there are no speech acts as such, but only situated speech acts or what he terms instantiated pragmatic acts (ipras or practs). He further points out that while speech acts, when used in the contexts are pragmatic acts, pragmatic acts need not be speech acts. Pragmatic acts deal with situated acts in communication. However, he believes that no conversation can be properly understood unless it is situated within the environment in which it is meant to be understood. Elaborating further on this, he states that, "there is only one force in any act of uttering, whether illocutionary or perlocutionary, and it is pragmatic, the force of the pragmeme".

The theory of pragmeme is situated within Pragmatic acts theory. In establishing the place of PAT in communication, Mey (2001) explains that in doing actual things with words, speech acts need to be located within a situational context. He explains that not only are speech acts situated in a context; the context itself situates the speech acts, it creates them, as it were.

Variables like context and background knowledge guide the meaning of linguistic items in utterances. This is because Pragmatic acts are situation derived and situation constrained (Odebunmi, 2006). For sequences to count as a particular pragmatic act, the circumstances (setting up) must be right; there need not be a speech act involved (of either bribing, making a request, etc.); it is the context that determines the nature of the pragmatic act; without "uptake", there cannot be a pragmatic act; however, the uptake can be cancelled by another, subsequent act.

The chart by Mey (2001) explains better (Figure 1).

The chart shows that pragmeme has 1) activity part and 2) textual part. The central part in the concept of "pragmatic act" is pragmeme (the generalized pragmatic act). A pragmeme can be instantiated through individual pragmatic act (Mey, 2001). This is termed "practs". An "allopract" or "pract", according to Mey is "a concrete and different realization of a particular pragmeme". The activity part of a pragmeme as shown in the model shows options that are available to participants (interlocutors) in a text. It includes speech acts, indirect speech acts, dialogue or conversational acts, psychological acts, prosody, physical acts, body moves, facial expressions or physiognomy, and body expressions. A speaker can choose any or combine several concepts in interaction. The textual part "contextual features that influence communication" is exhibited through concepts of inference, reference, relevance, voice, SSK, metaphor and metapragmatic joker. The activity part depends on textual part for its realization; and both 


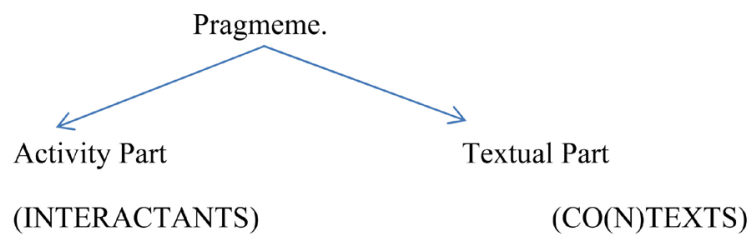

INF, REF, REL, VCE, “M”, MPH, SSK

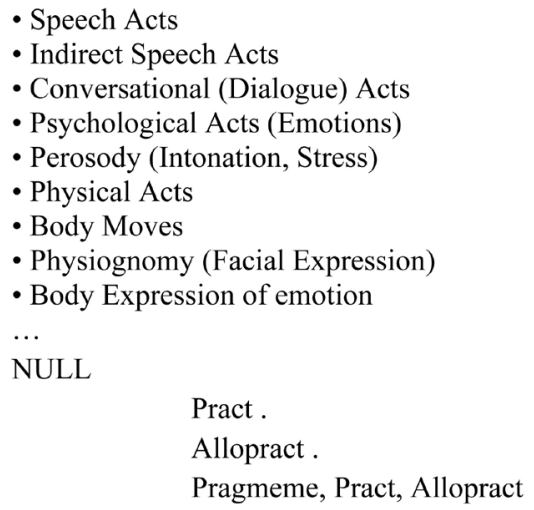

Figure 1. Mey’s (2001) model of pragmeme.

sides of pragmeme depend on context for meaning realization. The union between activity part and textual part produces a pract.

Mey (2001) uses the term pragmeme to describe multiple functions a unit of linguistic act can serve. He opines that it would be inappropriate to describe the said function as just speech acts, given that what we are dealing with is much more than just voicing but the actual performing of a societal function of language use-a pragmatic act. Consequently, every pract is at the same time an allopract. An Allopract then is an alternative of a specific pract, or in the words of Mey, a concrete and different realisation of a Pragmeme.

Mey's Pragmatics act theory is suitable for this study because it helps tease out the situated acts in a discourse either in a monologue, dialogue or multilogue. The speeches of both presidents can serve as monologues which have audiences. Though speeches are written, the ultimate goal is for it to be read out, so that people can listen and respond by acting on the content of the speech. This means that speeches, just like any utterances in any communication event, have the ability to spur listeners into actions and reactions. Therefore, theory is suitable in discerning pragmatic acts through which PMB and PNA-A connected with their citizens.

\section{Methodology}

Content analysis method which includes both qualitative and quantitative approaches is adopted for the current study (Elo \& Kyngäs, 2008). Speeches of both Presidents were downloaded from the internet. To ensure authenticity, the speech of PNA-A was also sought and obtained from the office of the chief press secretary to the President. Originally, PMB's speech came numbered 1 - 65; it was discovered that in some cases, some numbers have more than one practs. In 
all, 95 practs were noted. PNA-A's speech came as a narrative, and comprises 39 practs. The urgency of the need to curb the spread of coronavirus is paramount to everyone. The speeches were delivered at the peak of the fear of coronavirus pandemic. PMB delivered his speech on 29 March 2020, while PNA-A's was delivered on 11 March 2020. The text was divided into clauses. Pragmatic analytical tools of SSK and inference were used in the analysis. Practs in each complete unit of thought was noted as a basis for the analysis. Excerpts were purposively chosen; for PMB, 18 excerpts were chosen. They represent all categories of practs. For PNA-A, 13 excerpts were chosen. Both speeches were analysed to reveal pragmatic acts through which both presidents achieved broad pragmatic goals thereby connecting with their people. One excerpt was taken to illustrate each pract. To get the percentage of occurrence for each pract, the number of occurrence of each pract was done over the total number of practs times 100 for each president. The distribution of pragmatic acts was presented using pie chart to reveal the different percentages of the practs. The number of occurrence of each pract, the frequency, category of practs that formed the broad pragmatic goal was placed on a table. Under the analysis for each president's speech, excerpts were numbered as excerpt 1, 2, 3 etc. The excerpts were italicized to make them stand out from the analysis under them.

\section{Analysis and Discussion}

Distribution and Percentages of Different Practs in Both Presidents' Speeches

Objective One: The broad pragmatic acts in PMB and PNA-A.

\subsection{Practs in PMB's Speech}

The distribution in Figure 2 shows that PMB deployed more of Informing (48
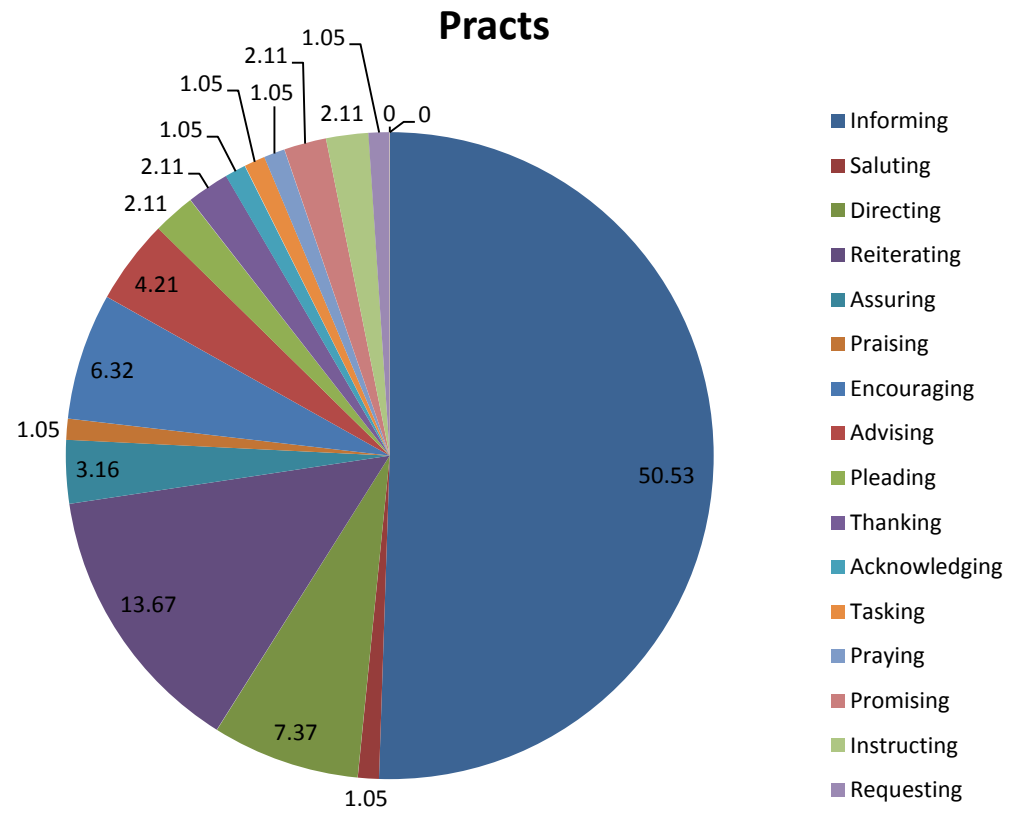

Figure 2. Percentages of practs by PMB. 
times, 50.53\%) practs in his address to the citizens. This is not surprising, because as his first speech about Covid-19 in Nigeria, Nigerians and the world expect him to let them know the steps government has taken, is taking and will take in a bid to curb the spread of the virus. Closely following Informing pract is Reiterating pract (13 times, 13.54\%); PMB reiterated important points that the audience need to take note of. Directing pract occurred 7 times (7.37\%); PMB made some directives which needed to be carried out in order to achieve the overall aim of combating the virus. Encouraging pract occurred 6 times (6.32\%). This was used to encourage Nigerians to do all they can to assist in seeing that the spread of the virus was curbed. Apart from encouraging, he also used Advising pract (4 times, 4.21\%) and Assuring pract 3 times (3.16). Pleading, Thanking, Promising and Instructing occurred 2 times (2.11\%) each. Practs of Saluting, Praising, Acknowledging, Tasking, Praying, and Requesting occurred once each (1.05\%) (Table 1).

\subsubsection{Excerpts from the Speech to Illustrate Each Category of Pragmatic} Goal in PMB's Speech to Reveal Achievements and Further Actions

Under this pragmatic goal, PMB deployed practs of Informing, and Assuring. Below are excerpts to illustrate each:

\section{(a) The Informing Pract}

Table 1. The broad pragmatic goals in both speeches.

\begin{tabular}{|c|c|c|c|c|c|c|c|c|c|c|c|}
\hline \multicolumn{6}{|c|}{ PMB } & \multicolumn{6}{|c|}{ PNA-A } \\
\hline Practs & Frequency & $\%$ & Goals & Frequency & $\%$ & Practs & Frequency & $\%$ & Goal & Frequency & $\%$ \\
\hline Informing & 48 & 50.53 & $\begin{array}{c}\text { To reveal } \\
\text { achievements }\end{array}$ & & & Informing & 20 & 51.28 & To reveal & & \\
\hline Assuring & 3 & 3.16 & $\begin{array}{l}\text { and further } \\
\text { action }\end{array}$ & 51 & 53.69 & Assuring & 2 & 5.13 & $\begin{array}{l}\text { achievements and } \\
\text { further action }\end{array}$ & 22 & 56.41 \\
\hline Directing & 7 & 7.37 & & & & Directing & 4 & 10.26 & & & \\
\hline Reiterating & 13 & 13.67 & & & & Reiterating & 4 & 10.26 & To instruct and & & \\
\hline Instructing & 2 & 2.11 & $\begin{array}{l}\text { To instruct } \\
\text { and direct }\end{array}$ & 27 & 28.41 & Ordering & 1 & 2.56 & direct & 10 & 25.64 \\
\hline Tasking & 1 & 1.05 & & & & Stating & 1 & 2.56 & & & \\
\hline Advising & 4 & 4.21 & & & & & & & & & \\
\hline Thanking & 2 & 2.11 & & & & Encouraging & 1 & 2.56 & $\begin{array}{l}\text { To pacify/ } \\
\text { encourage }\end{array}$ & 3 & 7.69 \\
\hline Acknowledging & 1 & 1.05 & To commend & 4 & 4.21 & Saluting & 2 & 5.13 & & & \\
\hline Praising & 1 & 1.05 & & & & Thanking & 2 & 5.13 & To commend & 2 & 5.13 \\
\hline Encouraging & 6 & 6.32 & & & & Pleading & 1 & 2.56 & To persuade & 1 & 2.56 \\
\hline Promising & 2 & 2.11 & To pacify/ & 10 & $10-2$ & Cautioning & 1 & 2.56 & To warn & 1 & 2.56 \\
\hline Praying & 1 & 1.05 & encourage & 10 & 10.03 & & & & & & \\
\hline Saluting & 1 & 1.05 & & & & & & & & & \\
\hline Pleading & 2 & 2.11 & 1 & & & & & & & & \\
\hline Requesting & 1 & 1.05 & suade & 3 & 3.16 & & & & & & \\
\hline 16 practs & 95 & 99.93 & & 95 & 100 & 11 practs & 39 & 99.99 & & 39 & 99.99 \\
\hline
\end{tabular}


The informing pract is divided into three: awareness creation of what government had done, what government was doing and what government would do in order to curb the spread of coronavirus: Examples:

(b) What the Government Had Done

Excerpt 1: we have introduced healthcare measure, border security, fiscal and monetary policies...

In this excerpt, $\mathrm{PMB}$, informed the citizens of federal government's commitment towards combating coronavirus. He further enumerated through mentioning areas where government had laid emphasis; this way, he got the citizen's confidence that the virus was being contained.

\section{(c) What the Government Was Doing}

Except 2: In Nigeria, we are taking a two-step approach.

The above excerpt further notified the citizens the step government was taking to curb the spread of the virus.

(d) What the Government Would Do

Excerpt 3: all inconsistencies in policy guidelines between Federal and state agencies will be eliminated.

In this excerpt, PMB used the auxiliary verb "will” to further let citizens know the effort government would engage in, in order to help in curbing the spread of the disease.

(e) The Assuring Pract

Excerpt 4: We remain committed to do whatever it takes to confront COVID-19 in our country.

This excerpt was an assurance to the people that government was up to the task of confronting the virus. This was to gain the people's confidence.

\subsubsection{The Next Broad Pragmatic Goal Was to Instruct and Direct}

To achieve this, the excerpts below were used:

(f) The Pract of Directing

Excerpt 5: ... I have directed that a three month repayment moratorium for all TraderMoni, MarketMoni and FarmerMoni loans be ...

In this excerpt, to further gain the citizens' confidence, PMB gave directives to the authorities involved. This was in order to assuage the effects of the lockdown.

\section{(g) The Pract of Reiterating}

Excerpt 6: ... the best and most efficient way to avoid getting infected is through regular hygienic and sanitary practices...

In excerpt 6, PMB reiterated in a way of indirect order on what individuals need to do to assist in curbing the spread of the virus. The SSK of PMB and the audience assisted the audience to infer the meaning of the clause "to avoid getting infected is through regular hygienic and sanitary practices...”.

\section{(h) The Pract of Instructing}

Excerpt 7: All businesses and offices within these locations should be fully closed during this period. 
This excerpt was an instruction of what people should do in order to assist in achieving the overall aim of the speech-the need to curb the spread of coronavirus.

(i) The Pract of Tasking

Excerpt 8: This common enemy can only be controlled if we all come together and obey scientific and medical advice

In this excerpt, PMB tasked the citizens of the need for commitment on their part to collectively obey medical advice.

(j) The Pract of Advising

Excerpt 9: take personal responsibility to support those who are vulnerable within their communities, helping them with whatever they may need

\subsubsection{The Next Broad Pragmatic Goal Was to Commend}

To achieve this, the excerpts below were used:

\section{(k) Thanking}

Excerpt 10: I will take this opportunity to thank all our public health workforce, ... on the front lines of the response for their dedication and commitment.

PMB showed appreciation by thanking all who had been in the fore-front of fighting coronavirus disease.

(1) Praising

Excerpt 11 ...I am personally very proud of Dr Ihekweazu for doing this on behalf of all Nigerians.

This excerpt was PMB's way of showing appreciation to the Director-General of the Nigeria Centre for Disease Control (NCDC). This was a way of encouraging more citizens to do more in combating the virus.

\section{(m) Acknowledging}

Excerpt 12: We are very grateful to see the emerging support of the private sector and individuals to the response as well as our development partners.

In this excerpt, $\mathrm{PMB}$ acknowledged the efforts of individuals who responded positively to combating the virus. This functioned as a nudge for others who could help too.

\subsubsection{The Next Broad Pragmatic Goal Was to Pacify}

To achieve this, the excerpts below were used:

\section{(n) The Encouraging Pract}

Excerpt 13: ... we must all see this as our national and patriotic duty to control and contain the spread of this virus...

In this excerpt, $\mathrm{PMB}$ achieved the pract of encouraging the citizens to see it as their duty to do all within their means to stop the spread of the virus. Citizens were able to understand the phrase "see this" as reference to the President's previous plea for individuals to adhere to the stipulated preventive measures.

(o) The Promising Pract

Excerpt 14: ... as a Government, we will avail all necessary resources to support the response and recovery... 
Like in the previous excerpts, this became meaningful in the context of SSK of the prevailing coronavirus pandemic.

(p) The Praying Pract

Excerpt 15: May God continue to bless and protect us all.

The reference to God in this excerpt showed man's frailty, vulnerability and limited knowledge/power in the face of the on-going pandemic; this served to bring hope and succor to all citizens including the President himself.

(q) The Saluting Pract

Excerpt 16: Fellow Nigerians.

In this pract, PMB first of all saluted Nigerians. This was in order to draw attention to the speech he was about to make.

\subsubsection{The Next Broad Pragmatic Goal Was to Persuade}

To achieve this, the excerpts below were used:

\section{(r) The Pleading Pract}

Excerpt 17: ... implore you again to strictly comply with the guidelines issued and also do your bit to support the Government and the most vulnerable in your communities...

In the context of coronavirus pandemic, the more privileged in the society understood that this part of the speech was directed to them-to assist the less privileged to be able to wade through the period of the pandemic.

(s) The Requesting Pract

Excerpt 18: At this point, I will ask that all contributions and donations be coordinated and centralized to ensure efficient and impactful spending.

This excerpt was a request from the President as part of measures to fully combat the virus. The utterance made meaning with SSK of coronavirus pandemic.

Having examined PMB's speech, let us now turn our attention to PNA-A's speech in order to analyse the practs therein.

\subsection{Practs in PNA-A's Speech}

The chart displays the practs in PNA-A's speech (Figure 3).

Figure 3 shows the distribution of the practs by PNA-A of Ghana. Like his Nigeria counterpart, PNA-A also deployed more of the informing practs. This came out 20 times, giving us $51.29 \%$. Closely following the informing pract was the practs of "reiterating" and "directing" similar to what we have in Figure 1. The saluting, assuring and thanking practs occurred 2 times each (5.13\%). Encouraging, pleading, cautioning, ordering and stating occurred once (2.56).

\subsubsection{The Broad Pragmatic Functions and Practs in PNA-A's Speech}

To reveal achievements and further action, PNA-A used the following practs:

(a) The Informing Pract

Like what we have under the informing pract for $\mathrm{PMB}$, the informing pract under PNA-A is also divided into three: awareness creation of what the government 


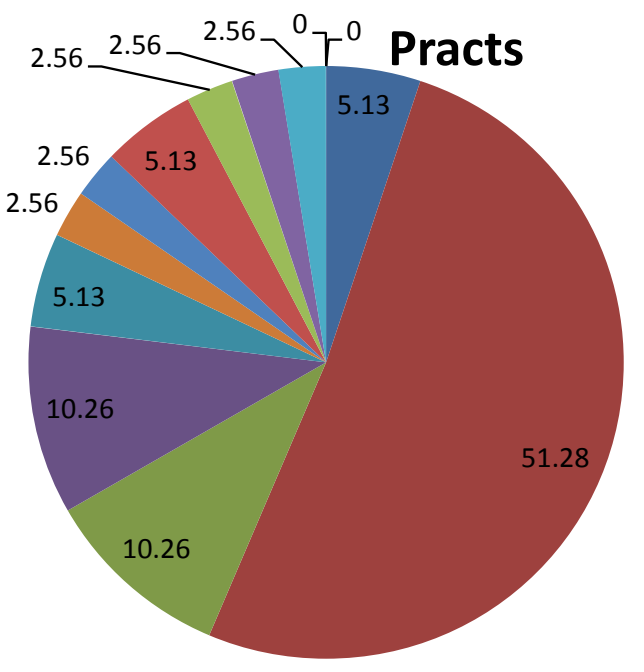

Figure 3. Percentages of practs by PNA-A.

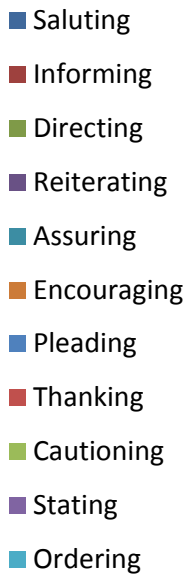

had done, what the government was doing and what the government would do in order to curb the spread of coronavirus.

It is not surprising that the majority of the practs in the address was the informing pract. Coronavirus was a new virus in the world as had never been seen before. Therefore, the President's preoccupation in this first address to the nation was to create the necessary awareness and inform the citizens the efforts of the government. The awareness was to let citizen know what government had done, what government was doing and what government would do in order to curb the spread:

\section{(b) What the Government Had Done}

Excerpt 1: The Ministry of Health has designated a quarantine facility that can hold infected persons, whilst regional hospitals are preparing isolation centres for holding suspected cases.

PNA-A in this excerpt revealed what measures government had taken towards curbing the spread of coronavirus. Though he did not mention the virus, SSK assisted the audience to know that the President was referring to coronavirus.

(c) What the Government Was Doing

Excerpt 2: ... we step up our preparedness to ensure that, beyond these initial, satisfactory measures, we adopt a "whole of Ghana" approach in adequately preparing for a possible hit within our borders.

In this excerpt, PNA-A informed the citizens of what government was doing and making moves towards curtailing the spread of the virus. Like in excerpt 1 , the hearer through SSK and inference understood what PNA-A was talking about. The dependent clause "...preparing for a possible hit within our borders", gave the inference of coronavirus.

(d) What the Government Would Do

Excerpt 3: For the time being, a weekly update on the situation will be provided by the Ministry. There will be more frequent updates, should the need 
arise.

In excerpt 3, the President assured Ghanaians of the readiness of government to combat Covid19 through constant/effective communication. This pract was made visible through the use of modal auxiliary "will" in the sentence "the situation will be provided". It showed what future action government would take. Through SSK, like in the excerpts above, the hearer understood the phrase "the situation" to refer to coronavirus.

(e) The Assuring Pract

Excerpt 4: I am confident that, together, with all hands on deck, we will be successful in weathering this storm.

In this excerpt (4), PNA-A, assured Ghanaians that the virus would eventually be surmounted through collective efforts of all. Through inference, the audience understood that the idiomatic expression "weathering this storm" referred to defeating the deadly disease.

\subsubsection{Under the Pragmatic Function of to Instruct and Direct, PNA-A Practed Using the Excerpts Below \\ (f) The Directing Pract}

Excerpt 5: Let us continue to observe the basic preventive behaviour, i.e. washing our hands regularly, using alcohol-based sanitisers, stopping shaking hands, and avoiding unnecessary close body contact.

Fighting coronavirus also requires giving directives on what people need to do. Excerpt 5 is an example of directives from PNA-A on what Ghanaians need to do to help in curbing the spread of the virus.

\section{(g) The Reiterating Pract}

Excerpt 6: I want to reiterate, as I indicated on $6^{\text {th }}$ March, and as the Ministry of Health has advised, that we have to revisit our custom of shaking hands...

In this excerpt, PNA-A re-emphasized important point that is key to curbing the virus. This excerpt showed that the President had already mentioned before the importance of individuals to minimize hand shaking.

\section{(h) The Ordering Pract}

Excerpt 7: I have, as at yesterday, ordered a suspension of all international travels by public officials.

In the bid to fight the virus, PNA-A had to take certain decisions which he believed would benefit and assist in curtailing the spread of the virus. In this excerpt, he ordered a suspension of all international trips.

(i) The Stating Pract

Excerpt 8: All of us need to adjust.

In this excerpt, PNA-A stated the obvious that all need to adjust; though he did not state the areas where people need to adjust, SSK that exists between PNA-A and Ghanaians helps to expand the meaning of the unmentioned "areas where people need to adjust". Parts of the areas where people need to adjust were found in the preceding excerpts: avoid shaking of hands, avoid international travels for the time being, regular sanitizing of hand etc. 


\subsubsection{The Pragmatic Goal of Pacification: Under This Goal, PNA-A Practed Using the Excerpts Below \\ (j) The Encouraging Pract}

Excerpt 9: Let us continue to observe the basic preventive behaviour, i.e. washing our hands regularly, using alcohol-based sanitisers, stopping shaking hands, and avoiding unnecessary close body contact.

PNA-A in this excerpt (9) encouraged citizens to join in the collective fight for the eradication of the virus. Though coronavirus was not mentioned, citizens know the preventive measures they need to observe.

\section{(k) The Saluting Pract}

Excerpt 10: May God bless us all, and our homeland Ghana, and make her great and strong.

In this excerpt, PNA-A, saluted the citizens, including himself. This was a way of encouraging Ghanaians and to give them hope that the country would be great again, posts Covid-19. The pronoun "us" in the utterance functioned to unify both the speaker and the citizens. It also brings the President to the level of the citizens, and also to make them feel a sense of togetherness.

\subsubsection{Under the Pragmatic Function of Commendation: PNA-A Practed Using the Excerpt Below \\ (1) The Thanking Pract}

Excerpt 11: We are grateful to the World Health Organisation (WHO), the World Bank, the International Monetary Fund, and friends of Ghana for the assistance they have, so far, provided.

PNA-A, in this excerpt, showed appreciation to organizations which had provided assistance to people of Ghana in the fight against coronavirus. SSK that existed between PNA-A and the citizens of Ghana helped to situate the meaning of this excerpt. The hearer of the speech could infer that the help PNA-A was talking about related to no other than coronavirus.

\subsubsection{Under the Pragmatic Function of Persuasion: PNA-A Practed Using the Excerpt Below}

\section{(m) The Pleading Pract}

Excerpt 12: I appeal to civil society organisations, schools, universities, faith-based organisations and places, ... to put in place mechanisms to caution and assist patrons on basic preventive measures.

The above excerpt showed the President's plea to different sectors of the economy to assist in the fight against Covid-19. The plea functioned to portray the humility of the President.

\subsubsection{Under the Pragmatic Function of Warning: PNA-A Practed Using the Excerpt Below}

\section{(n) The Cautioning Pract}

Excerpt 13: Fellow Ghanaians, all of us should, as much as possible, desist from all foreign travels, except the most critical ones, until there is a grip on the virus. 
The above excerpt illustrated part of PNA-A's caution to Ghanaians against engaging in external trips. It was part of preventive measures and decision taken by government to help in curbing the spread of the coronavirus.

Objective two: Words and phrases that act as contextual inferences/reference of coronavirus in both speeches

References to the Coronavirus through Situated Shared Knowledge/Inference by PMB and PNA-A (Table 2)

The words and phrases showed that both Presidents tapped on SSK of the existence of coronavirus between both Presidents and the citizenry. This was clearly seen in the use of words and phrases to refer to the virus at different parts of the speeches. In parts of the speech, PMB used single words as: "disease", and "it" to refer to the virus. He used phrases like: "health emergency", "economic crisis", "first case", "confirmed cases", "those infected", "this pandemic", "the outbreak", "the virus", "these cases", and "this common enemy" as metonyms to refer to coronavirus. On his own part, PNA-A to connect with citizens of Ghana, used words like: "pandemic", "case", "infections", "outbreak"; he also used phrases to refer to coronavirus such as: "the situation", "this fight", "this cause", "the disease", "the virus", "this crisis", "our fight", and "this storm". The hearer of the speeches, through SSK of coronavirus could make inference that the words and phrases all refer to the deadly virus. Both presidents deployed these words and phrases in order to avoid being repetitive. The uses of single words, phrases by both presidents to refer to coronavirus showed they had deployed

Table 2. Words and phrases both presidents used to refer to the coronavirus in their speech.

\begin{tabular}{cc}
\hline PMB & PNA-A \\
\hline Disease & Pandemic \\
Health emergency & Case \\
Economic crisis & Cases \\
First case & Outbreak \\
Confirmed cases & Infections \\
Those infected & Hit \\
This pandemic & The situation \\
The outbreak & This Fight \\
This virus & This cause \\
These cases & The disease \\
It & It \\
This common enemy & The virus \\
& This crisis \\
& Our fight \\
& This storm \\
\hline & \\
&
\end{tabular}


various options available to them as language users to refer to the virus without being repetitive. Without mentioning coronavirus, the hearer of the speeches knew that those words and phrases referred to the same thing. The overriding pragmatic function in both speeches was revealing of intentions of what steps both presidents were taking in order to curb the spread of coronavirus in Nigeria and in Ghana.

Objective Three: Similar/dissimilar practs in PMB and PNA-A speeches

The analysis revealed that $\mathrm{PMB}$ deployed a total of sixteen practs, while PNA-A deployed eleven. Irrespective of the number of times of occurrence of each of the practs in both speeches, eight practs were similar in both speeches. These are: informing, saluting, directing, reiterating, assuring, encouraging, pleading, thanking. These practs revealed the key intention of both presidents in making the speech-to curb the spread of coronavirus pandemic. The speeches of both presidents are understandable in the context of coronavirus pandemic. The urgency of the need to stop the spread of the virus necessitated the speeches. The context of the speeches interacts with acts to give the speeches the force they have. Greetings in the African context plays a key role in the opening of discourses, this probably explained why both presidents opened their speeches by first of all greeting the citizens, to draw their attention to the speech. Apart from the similar practs in both speeches, there are also dissimilar practs. PMB deployed practs like praising, advising, acknowledging, tasking, praying, promising, instructing and requesting; these are not found in the speech of PNA-A. PNA-A also used the cautioning, ordering and stating practs; PMB did not use any of the three. The reason for the dissimilarities could be as a result of the peculiarities of each country, and the political situation during the speech. Some of these peculiarities can be noted in 1) Size of the country: Nigeria, the most populous black nation in the world, has the population of over two hundred million people while Ghana is a little over twenty-nine million. 2) Language: Nigeria has over 500 ethnic languages spoken within the shores of the country while in Ghana there are about 11 of such languages. 3) Politics: Nigeria has fought a civil war that lasted for three years while Ghana has not experienced such. Therefore, the approaches both presidents adopt in addressing their people are usually significantly different from one another.

\section{Conclusion}

The context of a speech plays a great role in determining the meaning of words and phrases used in a speech. What this implies is that notable figures like presidents of countries should in public speeches deploy linguistic items which citizens can relate to. Since presidential speeches play crucial roles in determining the destiny of economies all over the world, it is pertinent that linguistic choices in speeches should reflect effective governance. All the practs in both presidents' speech point to the need for collective effort in fighting coronavirus. The social implication of the findings is that presidents of nations, irrespective of whatever 
topic they address their country on, the peculiarities of the country play a crucial role in linguistic choices they make and in how they present their speech to the populace. This study concludes that through the analysis of different practs in speeches, the thematic focus of a speech can be discerned. Both Presidents have successfully deployed the activity part and textual part which according to Mey (2001) is necessary for the production of practs in speeches.

\section{Conflicts of Interest}

The authors declare no conflicts of interest regarding the publication of this paper.

\section{References}

Ademilokun, M. (2015). Aspects of Attitudinal Meaning in Nigerian President Muhammadu Buhari's Inauguration Speech: An Appraisal Analysis. The African Symposium, 15, 3-10.

Adukpo, J. (2017). An Analysis of Register and Lexical Cohesion in Selected Political Manifesto in Ghana. M.Phil. Thesis, Winneba: University of Education.

Ayeomoni, O. M., \& Akinkuolere, O. S. (2012). A Pragmatic Analysis of Victory and Inaugural Speeches of President Umaru Musa Yar'Adua. Theory and Practice in Language Studies, 2, 461-468. https://doi.org/10.4304/tpls.2.3.461-468

Dadjo, S. (2018). Speech Act Analysis of President Akufo Addo's Discourses about Africa's Dependency on the West. Lettre, Sciences Humaines et Sociales, No. 13, 254-282.

Elo, S., \& Kyngäs, H. (2008). The Qualitative Content Analysis Process. Journal of Advanced Nursing, 62, 107-115. https://doi.org/10.1111/j.1365-2648.2007.04569.x

Fairclough, N. (1998). Language and Power. London: Longman.

Isa, S. S., \& Abaya, A. S. (2019). A Critical Discourse Analysis of Rhetorical Devices in the Campaign Speeches of Presidential Candidate Muhammadu Buhari and President Goodluck Jonathan in the 2011 Elections in Nigeria. Journal of Languages, Linguistics and Literary Studies (JOLLS), 8, 132-146.

Israel, P. C., \& Botchwey, E. (2017). Language and Politics: A Study of Presidential Speeches of Selected Ghanaian Leaders. WORD, 63, 1-61.

https://doi.org/10.1080/00437956.2016.1275358

Iyengar, S. (2005). Speaking of Values: The Framing of American Politics. The Forum, 3, 1-8. https://doi.org/10.2202/1540-8884.1093

Kantorgorje, C. (2020). An Epistemic Modality Analysis of Selected Inaugurals of Ghanaian Ghana. M.Phil. Thesis, Winneba: University of Education.

Koussouhon, L. A., \& Dosoumou, A. M. (2015). Political and Ideological Commitments: A Systemic Functional Linguistic and Critical Discourse Analysis of President Buhari's Inaugural Speech. International Journal of Linguistics and Communication, 3, 24-34. https://doi.org/10.15640/ijlc.v3n2a3

Kyei, N., Donkor, K., \& Appiah, M. (2020). Move Analysis of President Nana Addo Dankwa Akufo-Addo's 2017 Presidential Inaugural Speech (PIS). The International Journal of Humanities \& Social Studies, 8, 176-185. https://doi.org/10.24940/theijhss/2020/v8/i3/HS2003-058

Medubi, O., \& Amuda, F. (2016). I Belong to Everybody and I Belong to Nobody': A Socio-Pragmatic Analysis of President Buhari's Inaugural Address. IJRDO-Journal of So- 
cial Science and Humanities Research, 1, 1-31.

Mey, J. (2001). Pragmatics: An Introduction (2nd ed., pp. 210-227). Massachusetts, USA: Blackwell.

Odebunmi, A. (2006). A Pragmatic Reading of Ahmed Yerima's Yemoja, Attairu \& Dry Leaves on Ukan Trees. Intercultural Pragmatics, 3, 153-169. https://doi.org/10.1515/IP.2006.010

Okafor, V. C., \& Issife, G. U. (2017). Mood and Modality in Nigeria's President Muhammadu Buhari's Inaugural Speech: A Stylistic Study. International Journal of Linguistics and Literature (IJLL), 6, 27-40.

Ugoala, B. (2017). Communicative and Cohesive Devices in President Buhari's Directive to the Service Chiefs on the Urgency of Fighting Boko Haram Terrorism in Nigeria. Journal of Multimedia Technology \& Communication Studies, 3, 187-211. 


\section{Appendix}

President Muhammadu Buhari's Speech on Coronavirus

1) Fellow Nigerians,

2) From the first signs that coronavirus, or COVID-19 was turning into an epidemic and was officially declared a world-wide emergency, the Federal Government started planning preventive, containment and curative measures in the event the disease hits Nigeria.

3) The whole instruments of government are now mobilized to confront what has now become both a health emergency and an economic crisis.

4) Nigeria, unfortunately, confirmed its first case on 27th February 2020. Since then, we have seen the number of confirmed cases rise slowly.

5) By the morning of March 29th, 2020, the total confirmed cases within $\mathrm{Ni}$ geria had risen to ninety-seven.

6) Regrettably, we also had our first fatality, a former employee of PPMC, who died on 23rd March 2020. Our thoughts and prayers are with his family in this very difficult time. We also pray for a quick recovery for those infected and undergoing treatments.

7) As of today, COVID-19 has no cure. Scientists around the world are working very hard to develop a vaccine.

8) We are in touch with these institutions as they work towards a solution that will be certified by international and local medical authorities within the shortest possible time.

9) For now, the best and most efficient way to avoid getting infected is through regular hygienic and sanitary practices as well as social distancing.

10) As individuals, we remain the greatest weapon to fight this pandemic. By washing our hands regularly with clean water and soap, disinfecting frequently used surfaces and areas, coughing into a tissue or elbow and strictly adhering to infection prevention control measures in health facilities, we can contain this virus.

11) Since the outbreak was reported in China, our Government has been monitoring the situation closely and studying the various responses adopted by other countries.

12) Indeed, the Director-General of the Nigeria Centre for Disease Control (NCDC) was one of ten global health leaders invited by the World Health Organisation to visit China and understudy their response approach.

I am personally very proud of Dr Ihekweazu for doing this on behalf of all Nigerians.

13) Since his return, the NCDC has been implementing numerous strategies and programs in Nigeria to ensure that the adverse impact of this virus on our country is minimized. We ask all Nigerians to support the work of the Federal Ministry of Health and NCDC are doing, led by the Presidential Task Force.

14) Although we have adopted strategies used globally, our implementation programs have been tailored to reflect our local realities. 
15) In Nigeria, we are taking a two-step approach.

16) First, to protect the lives of our fellow Nigerians and residents living here and second, to preserve the livelihoods of workers and business owners to ensure their families get through this very difficult time in dignity and with hope and peace of mind.

17) To date, we have introduced healthcare measures, border security, fiscal and monetary policies in our response. We shall continue to do so as the situation unfolds.

18) Some of these measures will surely cause major inconveniences to many citizens. But these are sacrifices we should all be willing and ready to make for the greater good of our country.

19) In Nigeria's fight against COVID-19, there is no such thing as an overreaction or an under-reaction. It is all about the right reaction by the right agencies and trained experts.

20) Accordingly, as a Government, we will continue to rely on guidance of our medical professionals and experts at the Ministry of Health, NCDC and other relevant agencies through this difficult time.

21) I, therefore, urge all citizens to adhere to their guidelines as they are released from time to time.

22) As we are all aware, Lagos and Abuja have the majority of confirmed cases in Nigeria. Our focus therefore remains to urgently and drastically contain these cases, and to support other states and regions in the best way we can.

23) This is why we provided an initial intervention of fifteen billion Naira (N15b) to support the national response as we fight to contain and control the spread.

24) We also created a Presidential Task Force (PTF) to develop a workable National Response Strategy that is being reviewed on a daily basis as the requirements change. This strategy takes international best practices but adopts them to suit our unique local circumstances.

25) Our goal is to ensure all States have the right support and manpower to respond immediately.

26) So far, in Lagos and Abuja, we have recruited hundreds of Adhoc staff to man our call centres and support our tracing and testing efforts.

27) I also requested, through the Nigeria Governors Forum, for all State Governments to nominate Doctors and Nurses who will be trained by the NCDC and Lagos State Government on the tactical and operational response to the virus in case it spreads to other states.

28) This training will also include medical representatives from our armed forces, paramilitary and security and intelligence agencies.

29) As a nation, our response must be guided, systematic and professional. There is a need for consistency across the nation. All inconsistencies in policy guidelines between Federal and State agencies will be eliminated.

30) As I mentioned earlier, as at this morning we had ninety-seven confirmed 
cases. Majority of these are in Lagos and Abuja. All the confirmed cases are getting the necessary medical care.

31) Our agencies are currently working hard to identify cases and people these patients have been in contact with.

32) The few confirmed cases outside Lagos and Abuja are linked to persons who have travelled from these centres.

33) We are therefore working to ensure such interstate and intercity movements are restricted to prevent further spread.

34) Based on the advice of the Federal Ministry of Health and the NCDC, I am directing the cessation of all movements in Lagos and the FCT for an initial period of 14 days with effect from $11 \mathrm{pm}$ on Monday, 30th March 2020. This restriction will also apply to Ogun State due to its close proximity to Lagos and the high traffic between the two States.

35) All citizens in these areas are to stay in their homes. Travel to or from other states should be postponed. All businesses and offices within these locations should be fully closed during this period.

36) The Governors of Lagos and Ogun States as well as the Minister of the FCT have been notified. Furthermore, heads of security and intelligence agencies have also been briefed.

37) We will use this containment period to identify, trace and isolate all individuals that have come into contact with confirmed cases. We will ensure the treatment of confirmed cases while restricting further spread to other States.

38) This order does not apply to hospitals and all related medical establishments as well as organizations in health care-related manufacturing and distribution.

39) Furthermore, commercial establishments such as;

a) food processing, distribution and retail companies;

b) petroleum distribution and retail entities;

c) power generation, transmission and distribution companies; and

d) private security companies are also exempted.

40) Although these establishments are exempted, access will be restricted and monitored.

41) Workers in telecommunication companies, broadcasters, print and electronic media staff who can prove they are unable to work from home are also exempted.

42) All seaports in Lagos shall remain operational in accordance with the guidelines I issued earlier. Vehicles and drivers conveying essential cargoes from these Ports to other parts of the country will be screened thoroughly before departure by the Ports Health Authority.

43) Furthermore, all vehicles conveying food and other essential humanitarian items into these locations from other parts of the country will also be screened thoroughly before they are allowed to enter these restricted areas. 
44) Accordingly, the Hon. Minister of Health is hereby directed to redeploy all Port Health Authority employees previously stationed in the Lagos and Abuja Airports to key roads that serve as entry and exit points to these restricted zones.

45) Movements of all passenger aircraft, both commercial and private jets, are hereby suspended. Special permits will be issued on a needs basis.

46) We are fully aware that such measures will cause much hardship and inconvenience to many citizens. But this is a matter of life and death, if we look at the dreadful daily toll of deaths in Italy, France and Spain.

47) However, we must all see this as our national and patriotic duty to control and contain the spread of this virus. I will therefore ask all of us affected by this order to put aside our personal comfort to safeguard ourselves and fellow human beings. This common enemy can only be controlled if we all come together and obey scientific and medical advice.

48) As we remain ready to enforce these measures, we should see this as our individual contribution in the war against COVID-19. Many other countries have taken far stricter measures in a bid to control the spread of the virus with positive results.

49) For residents of satellite and commuter towns and communities around Lagos and Abuja whose livelihoods will surely be affected by some of these restrictive measures, we shall deploy relief materials to ease their pains in the coming weeks.

50) Furthermore, although schools are closed, I have instructed the Ministry of Humanitarian Affairs, Disaster Management and Social Development to work with State Governments in developing a strategy on how to sustain the school feeding program during this period without compromising our social distancing policies. The Minister will be contacting the affected States and agree on detailed next steps.

51) Furthermore, I have directed that a three-month repayment moratorium for all TraderMoni, MarketMoni and FarmerMoni loans be implemented with immediate effect.

52) I have also directed that a similar moratorium be given to all Federal Government funded loans issued by the Bank of Industry, Bank of Agriculture and the Nigeria Export-Import Bank.

53) For on-lending facilities using capital from international and multilateral development partners, I have directed our development financial institutions to engage these development partners and negotiate concessions to ease the pains of the borrowers.

54) For the most vulnerable in our society, I have directed that the conditional cash transfers for the next two months be paid immediately. Our Internally displaced persons will also receive two months of food rations in the coming weeks.

55) We also call on all Nigerians to take personal responsibility to support 
those who are vulnerable within their communities, helping them with whatever they may need.

56) As we all pray for the best possible outcome, we shall continue planning for all eventualities.

57) This is why I directed that all Federal Government Stadia, Pilgrims camps and other facilities be converted to isolation centres and makeshift hospitals.

58) My fellow Nigerians, as a Government, we will avail all necessary resources to support the response and recovery. We remain committed to do whatever it takes to confront COVID-19 in our country.

59) We are very grateful to see the emerging support of the private sector and individuals to the response as well as our development partners.

60) At this point, I will ask that all contributions and donations be coordinated and centralized to ensure efficient and impactful spending. The Presidential Task Force remains the central coordinating body on the COVID-19 response.

61) I want to assure you all that Government Ministries, Departments and Agencies with a role to play in the outbreak response are working hard to bring this virus under control.

62) Every nation in the world is challenged at this time. But we have seen countries where citizens have come together to reduce the spread of the virus.

63) I will, therefore, implore you again to strictly comply with the guidelines issued and also do your bit to support the Government and the most vulnerable in your communities.

64) I will take this opportunity to thank all our public health workforce, health care workers, port health authorities and other essential staff on the front lines of the response for their dedication and commitment. You are true heroes.

65) I thank you all for listening. May God continue to bless and protect us all.

PRESIDENT NANA ADDO DANKWA AKUFO-ADDO, ON GHANA'S ENHANCED RESPONSE TO THE CORONAVIRUS PANDEMIC, ON WEDNESDAY, $11^{\mathrm{TH}}$ MARCH, 2020

1) Fellow Ghanaians, good evening.

2) Five (5) days ago, on $6^{\text {th }}$ March, at the Baba Yara Sports Stadium, in Kumasi, on the occasion of our nation's sixty-third $\left(63^{\text {rd }}\right)$ Independence Anniversary Celebration, I gave an update on the measures put in by Government in response to the novel Coronavirus disease, which has so far affected some one hundred and eighteen thousand $(118,000)$ people across the world, resulted in the deaths of some four thousand (4000) people, and is wreaking havoc on the global economy.

3) WHO has now characterised it as a pandemic.

4) Prior to the address on $6^{\text {th }}$ March, I had visited the Kotoka International Airport in Accra, isolation and treatment centres at the Tema General Hospital and the Ridge Hospital in Accra, to see, at first hand, part of our state of readiness to deal with the virus, should any suspected case be recorded on our 
shores.

5) The continuous monitoring of the pandemic has revealed a number of significant developments, which require that the nation be brought up to speed on some additional measures we have to take to shore up our response mechanism.

6) Fellow Ghanaians, as you may have heard in the news, Burkina Faso, our northern neighbour, has confirmed her first two (2) cases of Coronavirus infections.

7) Togo, to our east, has one (1) confirmed case, and Cote d'Ivoire, to our west, also has one (1) confirmed case.

8) Several countries in Europe, like Italy, where we have quite a large population of Ghanaians, have, as a result of the surge in infections, escalated dramatically their response to the outbreak.

9) Thus far, our points of entry, such as our airports and land borders, continue to show satisfactory preparedness to screen all entrants into Ghana.

10) The Ministry of Health has designated a quarantine facility that can hold infected persons, whilst regional hospitals are preparing isolation centres for holding suspected cases.

11) Our country's two main research institutions, the Noguchi Memorial Institute and the Kumasi Centre for Collaborative Research, which have the capacity to investigate and confirm or otherwise suspected cases of Coronavirus infections, have been very supportive in this regard.

12) So far, they have found that the fifty-seven (57) suspected cases, as of today, Wednesday, $11^{\text {th }}$ March, have proved negative.

13) However, it is imperative that we step up our preparedness to ensure that, beyond these initial, satisfactory measures, we adopt a 'whole of Ghana' approach in adequately preparing for a possible hit within our borders.

14) In order to do so, at my prompting, the Minister for Finance has made available the cedi equivalent of one hundred million United States dollars to enhance our Coronavirus preparedness and response plan, that is to fund expansion of infrastructure, purchase of materials and equipment, and public education.

15) I have, as at yesterday, ordered a suspension of all international travels by public officials.

16) Except for critical assignments, which will have to be authorised by the Chief of Staff at the Office of the President, all public officials are to remain within the jurisdiction, until further notice.

17) Video conferencing facilities and other technological tools are to be utilised, whenever possible, for international engagements.

18) I have also instructed further enhancements of the protocols for in-bound traffic from already affected countries.

19) Fellow Ghanaians, all of us should, as much as possible, desist from all foreign travels, except the most critical ones, until there is a grip on the virus. 
20) The Ministry of Information is leading a nationwide public education campaign on preventive measures that we all must observe to ensure that we are able to control the spread of infections, should we record any infections in the country, which, mercifully, so far, we have not, but which, by the law of averages, we shall.

21) For the time being, a weekly update on the situation will be provided by the Ministry.

22) There will be more frequent updates, should the need arise.

23) I want to reiterate, as I indicated on $6^{\text {th }}$ March, and as the Ministry of Health has advised, that we have to revisit our custom of shaking hands, and stop doing so completely, and we must cover our mouths when we cough or sneeze.

24) This fight, fellow Ghanaians, cannot be that of Government alone. It is for all of us.

25) I urge the media to join this cause fully, and help disseminate effectively information on the dos and donts of the disease.

26) The information to be put out, however, must be that approved by health authorities, and not just from any piece of literature found on the internet, as false materials are already being spread from other jurisdictions.

27) I appeal to civil society organisations, schools, universities, faith-based organisations and places, which harbour large gatherings, such as classrooms, lecture halls, meetings, parties and funerals, to put in place mechanisms to caution and assist patrons on basic preventive measures.

28) I was encouraged to note that, at two well-attended funerals I participated in over the weekend, in Ashanti, people were observing the injunction against shaking hands.

29) All of us need to adjust.

30) Let us continue to observe the basic preventive behaviour, i.e. washing our hands regularly, using alcohol-based sanitisers, stopping shaking hands, and avoiding unnecessary close body contact.

31) Government is analysing the potential impact to our economy of the virus, and will trigger the relevant response to minimise it.

32) We have begun to engage with the domestic pharmaceutical industry to assist in producing as much of the logistics required to prevent and combat the virus as is possible under the circumstances.

33) Indeed, we must take advantage of this crisis to strengthen our domestic productive capacity, so we can advance our self-reliance, and reduce our dependence on foreign imports.

34) Necessity, they say, is the mother of invention.

35) We are grateful to the World Health Organisation (WHO), the World Bank, the International Monetary Fund, and friends of Ghana for the assistance they have, so far, provided, and for the pledges made in support of our fight.

36) We shall continue to work with them to defeat the spread of the virus. 
37) I am confident that, together, with all hands on deck, we will be successful in weathering this storm.

38) May God bless us all, and our homeland Ghana, and make her great and strong.

39) I thank you for your attention. 